\title{
EXAMINATION OF WATER QUALITY FROM THE YARQON RIVER (CENTRAL ISRAEL) USING THE GLASS SLIDE METHOD TO DEFINE ALGAL VEGETATIVE ACTIVITY (IN VITRO)
}

\author{
M. TAVASSI* - S. BARINOVA - E. NEVO \\ The Algology Laboratory in the Institute of Evolution, University of Haifa \\ Mount Carmel, Haifa 31905, Israel \\ (phone: +972-4-8249697; fax: +972-4-8246554) \\ *Corresponding author \\ e-mail:mtavasi@study.haifa.ac.il \\ (Received 29 $9^{\text {th }}$ August 2007 ; accepted $15^{\text {th }}$ March 2008)
}

\begin{abstract}
The provision of uniform, artificial substrates for periphytic colonization has a long history, and it is the most widespread of all the techniques applied to study algal periphyton activity. The Yarqon River is one of the largest coastal rivers in Israel. An experiment for the determination of algal vegetative activity in the artificial pools, using the glass method, from the Yarqon River stations was conducted during the period from 8.11.06 till 6.12.06. During the experiment we revealed the colonization's speed of substrates and the activity of self-purification processes at different stations of river. The artificial colonization of substrates by algae during the rainy period takes about 2-3 weeks. Chlorophyll, which was used as a trophic marker, revealed ultra-oligotrophic or oligotrophic levels in pool I. At pools II and III levels were either oligo-mesotrophic or eutrophic. These results corresponded to the gradient of organic matter in each experimental pool.The algal diversity found on glass slides represented about 10-15 species for each pool. During the experiment, cells from pool I were about 1-2.5 $\mu \mathrm{m}^{3}$, and at pool Ii cells were about $0.1-1.4 \mu^{3}$. The increase of the ecosystem's entropy is indicative of environmental stress. This criterion, which is based on diversity dynamics, cell counts, and biomass may be used for monitoring the quality of water and aquatic ecosystems in the rivers of Israel.
\end{abstract}

Keywords: glass side method, algae, diversity, density, artificial substrate, chlorophyll, ecology, Israel.

\section{Introduction}

Nowadays, great attention is given to biological monitoring to assess the quality of aquatic ecosystems and to complete chemical and physical analyses. Aquatic organisms that integrate all biotic and abiotic parameters in their habitat can provide a continuous record of environmental quality and reveal various environmental changes of natural and anthropogenic origin. Benthic algae, diatoms in particular, possess many of the attributes required for monitoring organisms (McCormick, Cairns 1994; Lowe, Pan 1996): they are widely distributed and occupy an essential position at the base of aquatic food-webs as important primary producers in many freshwater environments; they are fixed to substrates, therefore integrating real conditions of the habitat, and respond more rapidly to environmental changes than higher level organisms because of their short life cycle; in addition, algal assemblages are species rich, composed of tens of taxa with various environmental tolerances and preferences. The provision of a uniform artificial substrate for periphytic colonization has a long history, and it is the most widespread of the techniques applied to studies of algal periphyton activity. One of the advantages of using artificial substrates is the possibility to determine the exact age of the algal community growing on them. If glass slides are used, it is not necessary to scrape off the algae from the substrate; the slides can be examined directly under the microscope (Gold et al. 2002). This method has many advantages: (a) not a single 
species is lost or destroyed, (b) interrelations between species can be studied more accurately, and (c) quantitative measurements are possible.

The Yarqon River is one of the largest coastal rivers in Israel. There is a clear distinction, based on water quality, between the upper and the central sections. While the upper section is relatively unperturbed with a low nutrient level, the central section is highly impacted by municipal effluents via the Qane tributary (Gafny et al. 2000). Tavassi et al. $(2004,2007)$ classified the level of water quality by evaluating the value of the Water Quality Index (WQI), basically a mathematical means of nine water quality parameters, along the Yarqon River. The upper section had a WQI value that represented good water quality, while water from the upper segment of the central section corresponded to fair water quality, which could be related to the confluence with the Qane tributary, where municipal effluents from a wastewater treatment plant entered the Yarqon River.

The quality of surface water is determined by nutrient loads penetrating the water basin, as well as the intensity in which self-purification processes occur. The algae serve as primary producers in the nutrients' utilization process; in rivers they develop on substrates. The intensity of the self-purification process is directly linked with the amount of nutrients and the speed of their utilization. Within the water monitoring framework in countries of the European Union, the rivers' periphyton is monitored (European Parliament 2000). For this purpose, the species composition in the algal assemblage, the presence of indicator species, abundance, species biomass in the community as well as chlorophyll concentrations are determined (Cardoso et al. 2005). Observation of substrates occupation is recommended during the vegetation period (Ács et al. 2005).

We know after several years of investigation of Israeli rivers that the algae are more abundant in the winter rainy season. In order to make any conclusions regarding the intensity of proccesses, it is essential to determine the attributes of four general classes: (1) taxonomic composition, (2) species richness and diversity, (3) tolerance/intolerance, and (4) trophic structure (King, Richardson 2003). An experiment for the determination of the algal vegetative activity in the streams of the Yarqon River was conducted during the period from 8.11.06 till 6.12.06. The purpose of this study was to reveal the speed of substrate colonization, the activity of the self-purification processes under various organic loads, and reveal trophic level by chlorophyll concentration, algal diversity and abundance (Table 1). This study was based on water collected from the Yarqon River in October 2006 from three different sites (Figure 1): pool I contained water collected from an upper section; pool II contained water from the upper section that was diluted with water from the Qane tributary at a ratio of 5:1; and pool III contained water collected next to the effluent of the Qane tributary of the Yarqon River. 
Table 1. Trophic classes according to chlorophyll and algal cells number (Felfoldy, 1987)

\begin{tabular}{lcc}
\hline Trophic classes & $\begin{array}{c}\text { Chlorophyll } \\
\mathrm{mg} / \mathrm{m}^{3}\end{array}$ & $\begin{array}{c}\text { Algal cells number } \\
10^{6} / 1\end{array}$ \\
\hline atrophic & 0 & 0 \\
ultra-oligotrophic & $<1$ & $<0.01$ \\
oligotrophic & $1-3$ & $0.01-0.05$ \\
oligo-mesotrophic & $3-10$ & $0.05-0.1$ \\
mesotrophic & $10-20$ & $0.1-0.5$ \\
eso-eutrophic & $20-50$ & $0.5-1$ \\
eutrophic & $50-100$ & $1-10$ \\
eu-polytrophic & $100-200$ & $10-100$ \\
polytrophic & $200-800$ & $100-500$ \\
hypertrophic & $>800$ & $>500$ \\
\hline
\end{tabular}

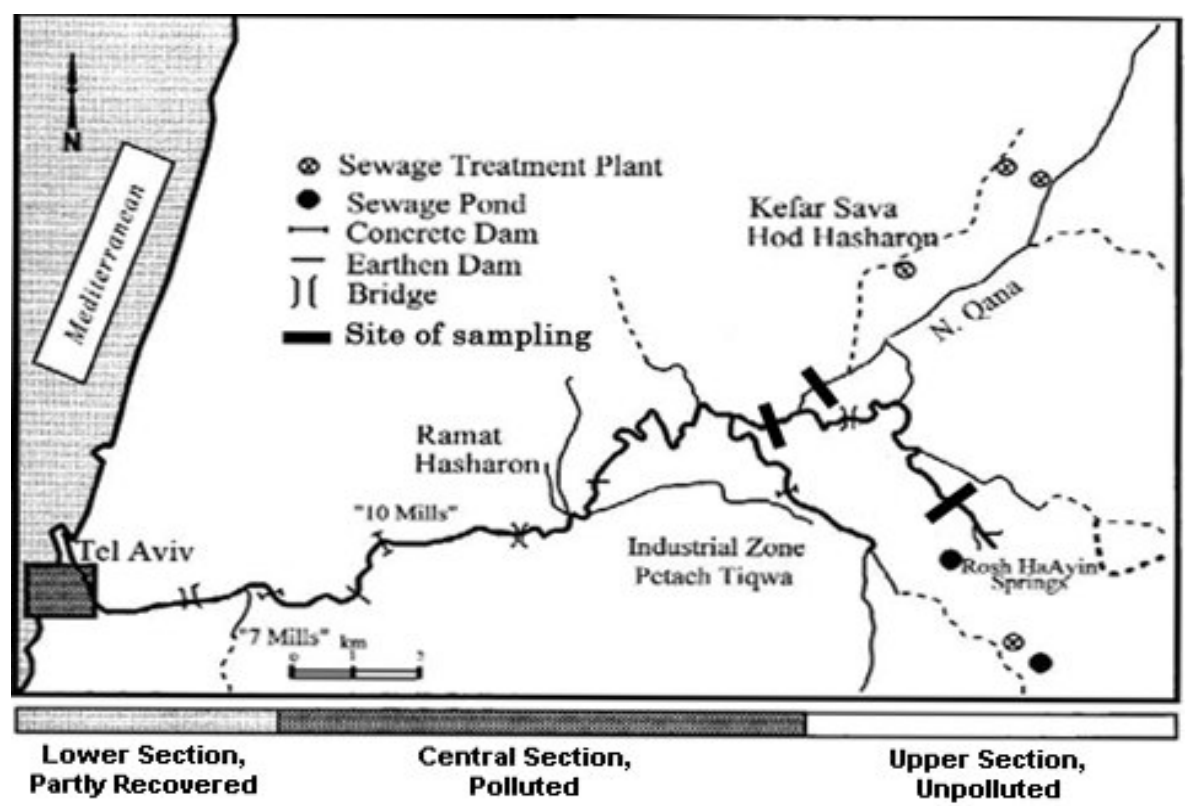

Figure 1. Region of investigations: Sampling stations on the Yarqon River

\section{Materials and methods}

The experiment was conducted in vitro on artificial substrates. Water samples (each 10 liters) as well as substrates and algae samples were collected from the habitats at the three sampling stations in the Yarqon River (Figure 1). For each sampling station the collected water, substrate, and algae where mixed together in a plastic container of 10 liters.

The pool-shaped containers were mixed and placed on the roof of one of the buildings at Haifa University. Daily measurement of temperature, conductivity, 
mineralization, and $\mathrm{pH}$ were performed using the HANNA HI 9813 apparatus and a thermometer. Glass slides served as the artificial substrates. They were placed horizontally in parallel to the water surface on buoys at a depth of $5 \mathrm{~cm}$ (Ács et al. 2005).

Measeurments of chlorophyll concentration on the glass slides and the nitrate concentration in the water were performed at 7-day intervals. The determination of chlorophyll concentration on glass slides was performed on the algal growth removed from a $10-\mathrm{cm}^{2}$ area on each slide. We were chosen methanol method because our algal communities was very diversed and enriched diatoms and cyanoprokaryotes (Thompson et. al. 1999). The chlorophyll concentration was determined in 3 repetitions using the spectrophotometric method for methanol extracts (Wetzel, Westlake 1969). In parallel to the chlorophyll concentration measurements were taken every The purpose of this study was to reveal the speed of substrate colonization, the activity of the selfpurification processes under various organic loads, and reveal trophic level by chlorophyll concentration, algal diversity and abundance 7 days and the presence of algal species were determined: their abundance/number and biomass on each slide. The identification of algal species on the surface of the glass slides was performed using a dissecting Swift microscope under magnifications of 800. Cell counting for each species was performed via the direct counting method.

The existent methods for calculating periphyton algae on natural substrates are time consuming and complicated (Biggs 1988, 1996; Barinova, Medvedeva 2004; Sladečkova 1962). In our case, for artificial substrates, it was possible to simplify things, we used a widely known method (PhycoTech 2007), in which the accretions grow on a flat surface with known area. Counting of cells in each field of view $(330 \times 330 \mu \mathrm{m})$ was repeated 10-100 times for each species, and the average was registered. The final data appear in units of cells $/ \mathrm{cm}^{2}$. The calculation of the biomass was performed using the average volume of cells for each species. The average cell volume was determined by the measurement of numerous cells of the species and then looking at them using the known volume of a similar geometrical body (Hillebrand et al. 1999). The obtained cell volumes were multiplied by the previously obtained cell numbers.

\section{Results and discussion}

During the experiment period, water temperature range varied between $17-21^{\circ} \mathrm{C}$ for the whole month. The $\mathrm{pH}$ values (Table 2) were consistently higher, along all the periods of the experiment, comparing pool III with pool II and pool I. The fluctuating changes in electric conductivity and mineralization (TDS) seem to have opposite trends (Figure 2), while for the first two weeks there was a moderate decreasing, which could be related to the self-purification process, for the following two weeks it sharply increased, which could be related to evaporation of the water from the artificial pools. However, at pool I the decreasing trend continued only for 8 days, meaning shorter selfpurification process needs. In addition, it's reflecting the general differences between total dissolved solids in the water of upper section (pool I) and in the water of central section (pool III). 
Table 2. The $p H$ value in the artificial pool for 28 days.

\begin{tabular}{|l|l|l|l|}
\hline Pool & Min. & Max. & Ave. \\
\hline I & 6.5 & 7.2 & $6.8 \pm 0.2$ \\
\hline II & 6.7 & 7.4 & $7.1 \pm 0.2$ \\
\hline III & 7.0 & 7.7 & $7.4 \pm 0.3$ \\
\hline
\end{tabular}

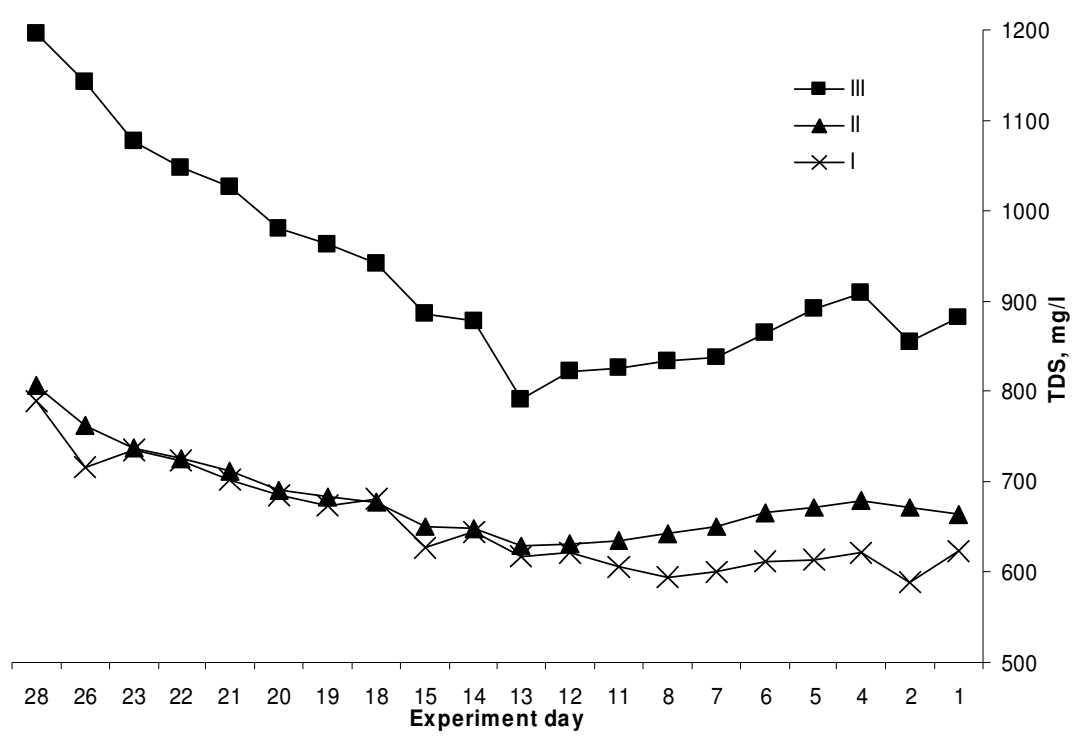

Figure 2. Total Dissolved Solids (TDS) fluctuation in the experimental pools.

The chlorophyll concentration represents the biomass of the periphyton community that attached on the glass slide. In rivers the periphyton abundance and composition correlates to the streaming speed (Bourassa, Cattaneo 1998) and the nutrients' concentration (Biggs 2000). Trophic status classification, based on chlorophyll concentration and cell number that was adopted for our data (Padisák et al. 1991; Dodds et al. 1998) for pool I where the chlorophyll concentration was very low during the whole experiment time, consistent with the utra-oligo- till oligo- level, while in pool II and III the concentration was much higher represent oligo-meso- till eutrophic level. The peak of the chlorophyll at pool II and III appeared in the second week, increasing by 2.2 and 2.8 in compare to the first week, while in pool I peak appeared at the third week (Figure 3). In pool III the chlorophyll concentration was much higher compared to the two other concentrations, i.e., in the second week, chlorophyll concentration was higher $\sim 4.4$ times than pool II, and $\sim 68$ times higher than pool I (Figure 3 ). 


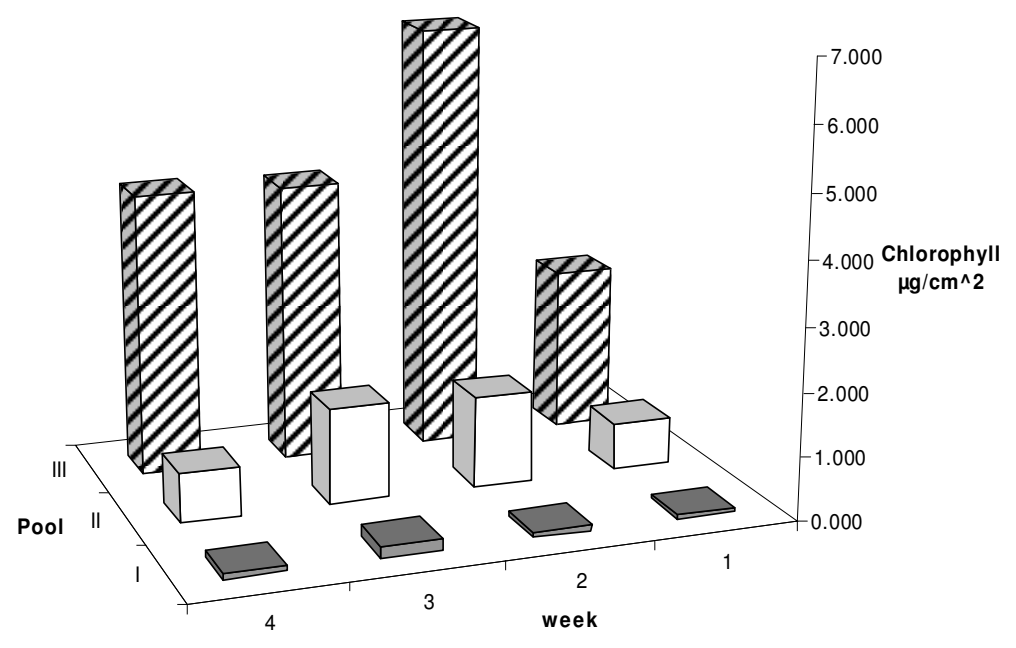

Figure 3. Fluctuation of chlorophyll concentration in the experimental pools.

Algal abundance in pool I reached a maximal level in the $3^{\text {rd }}$ week of our experiment. The number of species kept growing even in the $4^{\text {th }}$ week (Figure 4 ). These facts are indicative of a healthy ecosystem that allowed the development of algal community with high diversity. At pool II, despite algal diversity reaching a maximal level in the $3^{\text {rd }}$ week, the number of cells kept growing with high rates (Figure 5). However, at pool III algal diversity and abundance changed almost simultaneously reaching a maximal level in the $2^{\text {nd }}-3^{\text {rd }}$ week of our experiment (Figure 6), which may be related to the adaptation of the algal community to the high-organic load condition.

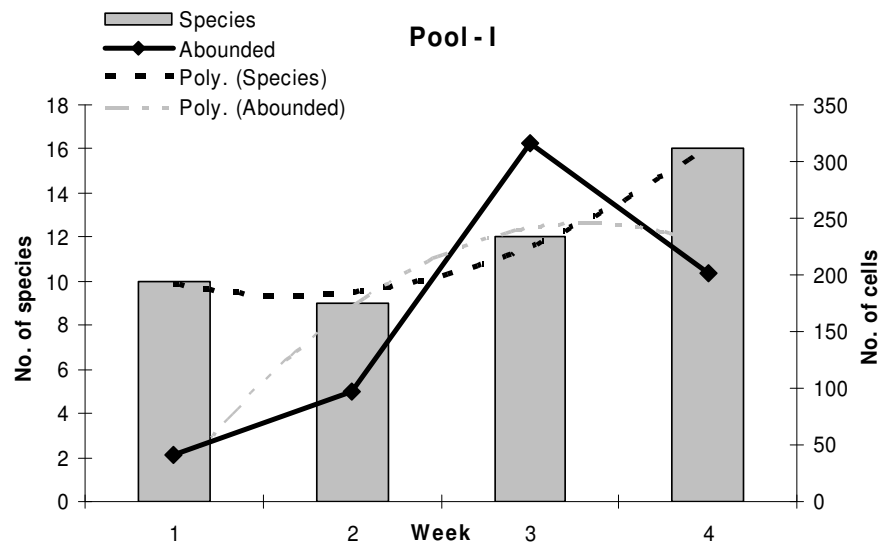

Figure 4. Algal diversity and abundance fluctuation in the pool I. 


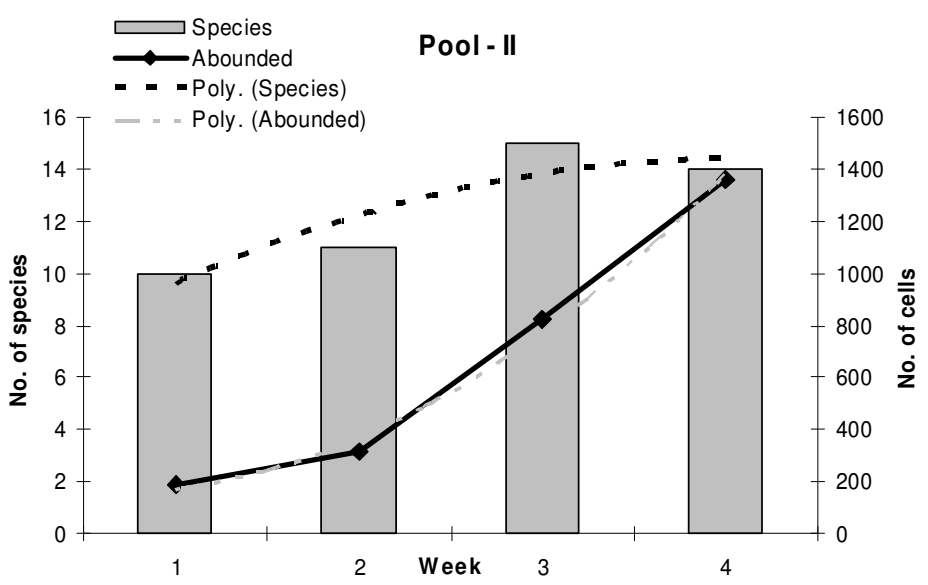

Figure 5. Algal diversity and abundance fluctuation in pool II.

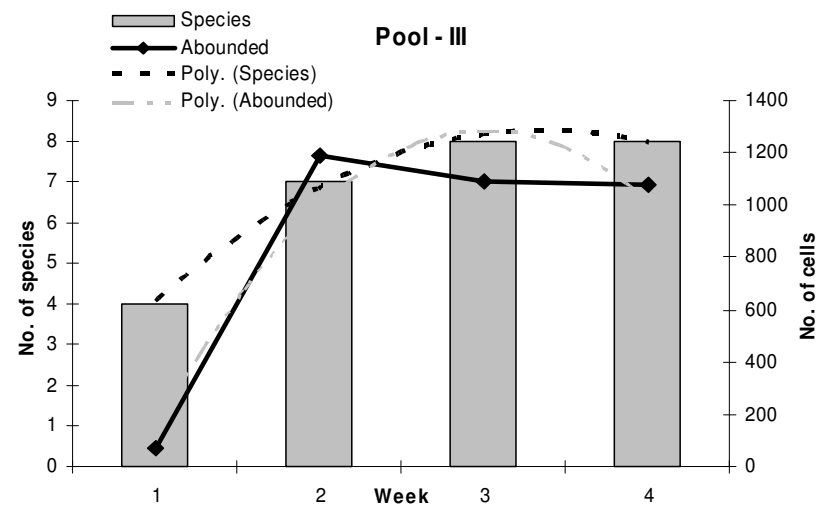

Figure 6. Algal diversity and abundance fluctuation in pool III.

From an analysis of taxonomic dynamics of the algal composition in the substrate colonization process, it can be seen that in pool I was maximal number of species and the maximal algal diversity with prevailing of Diatoms (Figure 7). This shows us that the experimental conditions were sufficient good for their development.

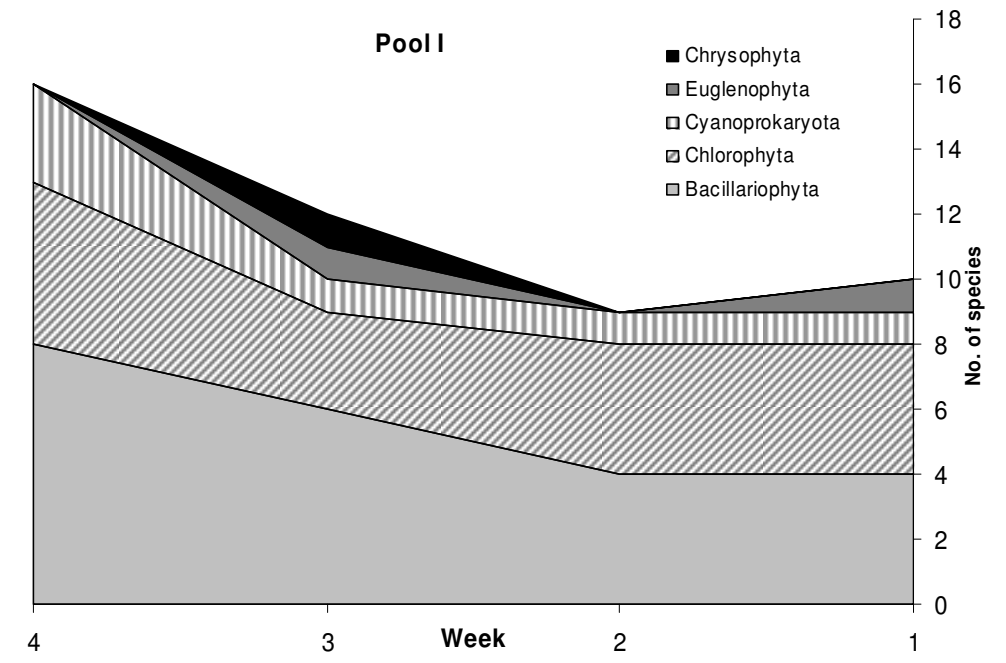

Figure 7. Taxonomic dynamics of the algal composition in the substrate colonization process in pool $I$. 
In pool II the maximal number of species and the maximal algal divisional variety were observed in 3 week, where the no. of green algae was increasing (Figure 8). This shows us that the mixed condition in the pool II were more enriched with nutrients.

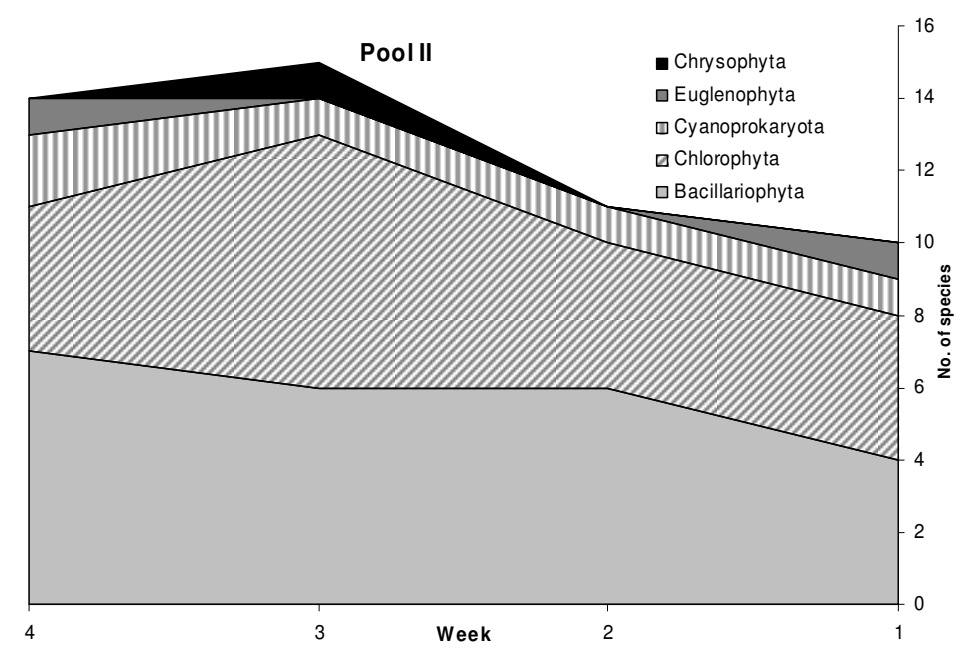

Figure 8. Taxonomic dynamics of the algal composition in the substrate colonization process in pool II.

However, in pool III we can see an increasing no. of species throughout the experiment. It's defined the higher number of euglenoid species and cyanoprokaryotes in compare to other taxonomic division (Figure 9). This increase could be related to the higher content of nutrients in the water from the Qane tributary.

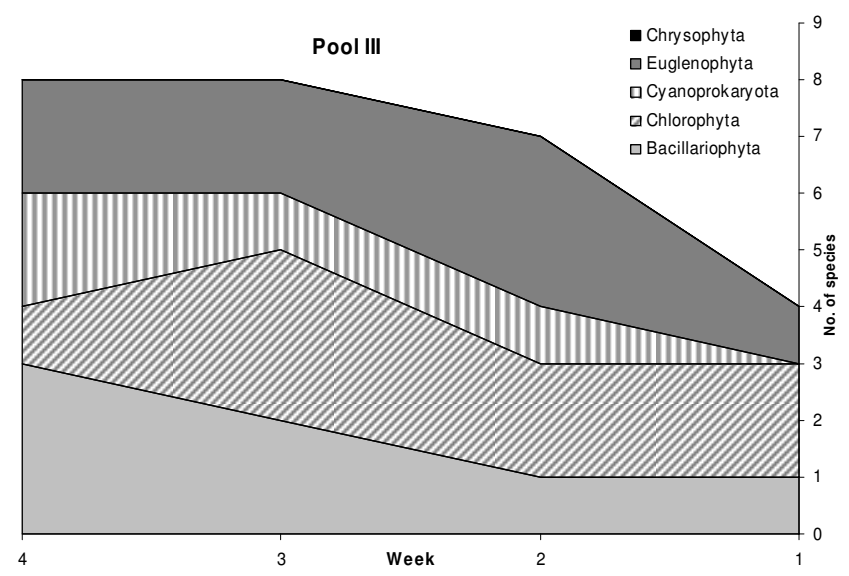

Figure 9. Taxonomic dynamics of the algal composition in the substrate colonization process in pool III.

The correlation between the number of cells and their total biomass reflects the condition of the ecosystem. Usually, in a case like this, the Shannon index is employed; however, we feel that the regularity can be better observed via the specific cell volume value.

In stable ecosystems the cells are bigger, and the growth rate isn't high. However, when the ecosystem is under the influence of stress factors (such as anthropogenic influence, usually caused with increasing of the trophic base) there is a pick in 
productivity, caused with increasing of total cells number and significant decreasing of cell volume.

In Figure 10, we can see in pool I simultaneous trends of algal development in respect to biomass and cell abundance with a maximum on 2 or 3 weeks. However, biovolume of cells very rapidly decrease, and trend line of this process was opposite for biomass and abundance trends. During the third week cells number on substrate was much higher, and the bio-volume was lower than in the whole experiment time. This may be an indication of stress on the ecosystem that provides the Qane tributary.

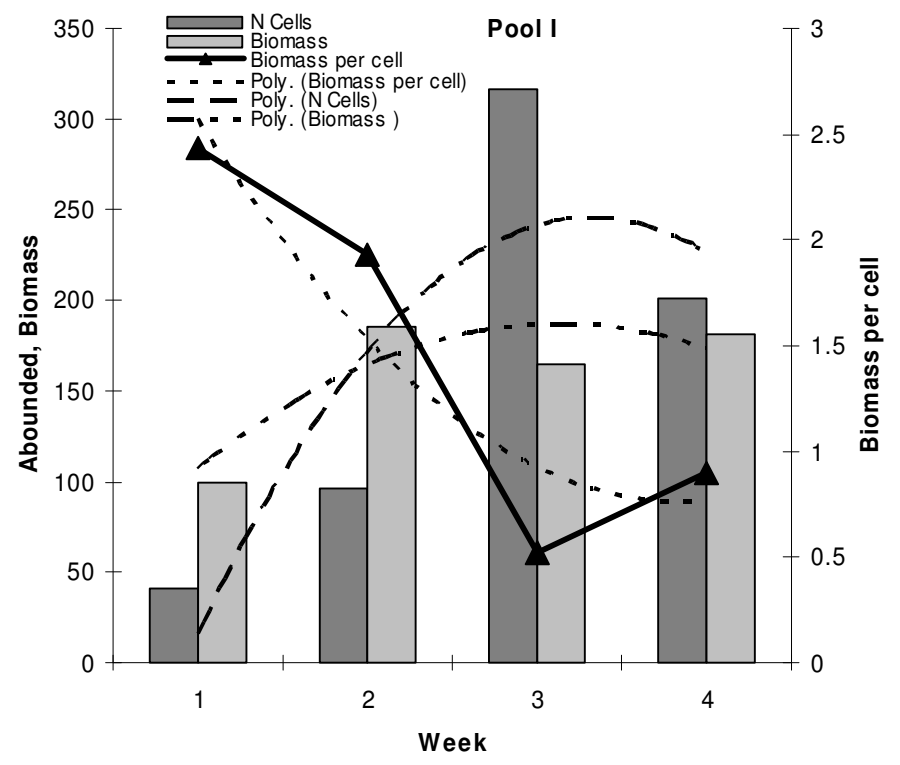

Figure 10. Algal biomass and cell numbers fluctuation in pool I.

In pool II biomass and abundance of algae were increased throughout the experiment, even in the last week (Figure 11). However, the bio-volume of cells was decreased in the second week. In comparison to pool I we see that the process of primary production was more rapid, and the ecosystem potential was not under nutrient limitation.

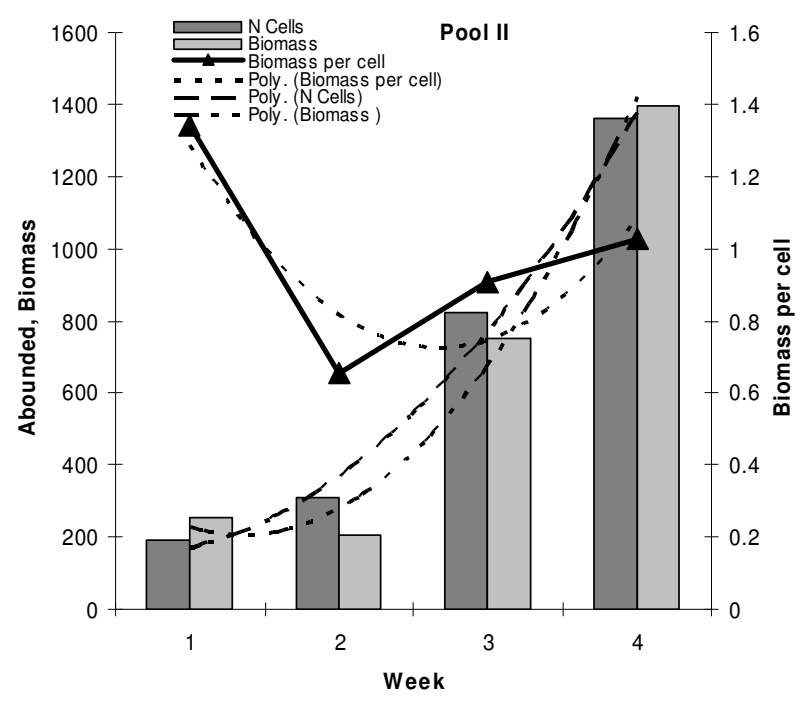

Figure 11. Algal biomass and cell numbers fluctuation in pool II. 
In pool III maximum algal biomass and abundance was revealed in the second week with a higher increase compared with the first week (Figure 12). These characteristics indicate a high level of organic load in the Qane tributary. However, a fivefold decrease of bio-volume of the cells from the first week to the third week shows toxic influence to the ecosystem health.

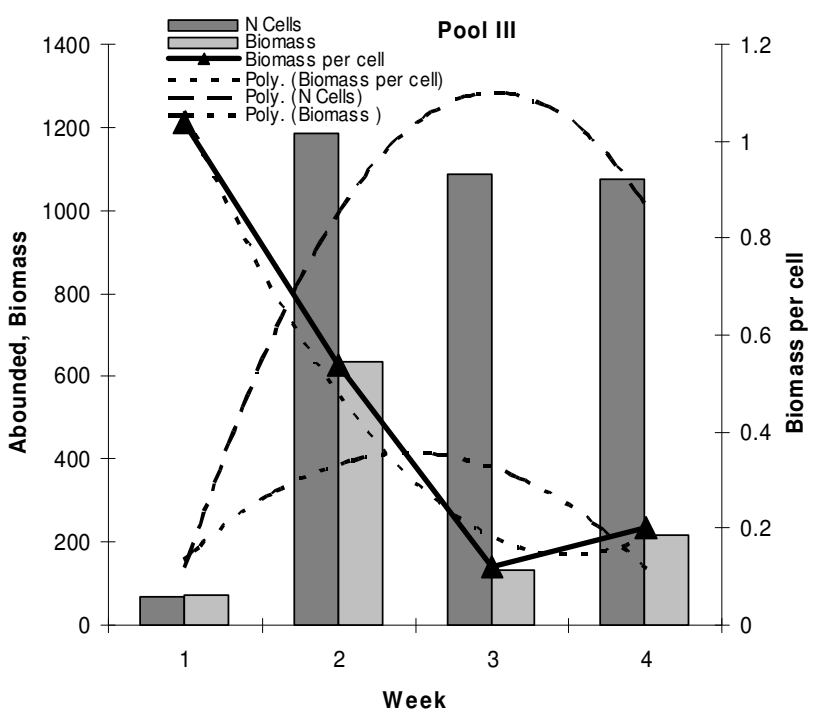

Figure 12. Algal biomass and cell numbers fluctuation in pool III.

Throughout, the experimental calculations show significantly decreasing of the biovolume of cells after the second and third week. Therefore, our experiment was influenced by some level of stress.

It is a known fact that the higher the diversity, the more complex is its structure (Stirling, Wilsey 2001). However, if the trophic base grows in the early stages of the ecosystem's development, it leads to a steep rise in both diversity and biomass, followed by a plateau reached for all indices (Tilman 1996), exactly as observed in pool I.

In addition, in pools II and III there is a significant increase in the number of nondiatom algal species, mainly green and euglenoid algae, which indicates the presence of a large trophic base (larger than the one presented in pool one) (Heiskary, Markus 2003). In pool I the diversity reached its peak in the last week. The data reflect the potential possibility of the self-purification process even after four weeks that were followed by the lowering of the trophic level. In the pools that were enriched by nutrients (II-III), we can see a stabilization of species diversity after the second and third weeks.

In this manner when comparing the diversity and abundance charts (Figures 4-6, 1012) it can be seen that the water from the Nofarim station (pool I) is relatively unperturbed with a lower nutrient level than the water from the two other stations. The temporal variability of ecosystem properties decreases with increasing diversity (Tilman 1996). Therefore, we see that the ecosystem in pools II and III is under the influence of a stress factor throughout all of our experiment.

A comparison of chlorophyll dynamics and cell abundance (Figure 3, 10-12) shows that after the passing peak in chlorophyll concentration at all experimental pools there is a decline in its concentration, accompanied by a decrease in cell size. This allows us to 
assume that the weak influence of stress factors continued during the whole experiment. However, these stress factors did not lead to the destruction of the ecosystem, since the biodiversity may be used as a buffer against environmental fluctuations (Thébault, Loreau 2005).

\section{Conclusion}

As can be seen from the above data and calculations, water temperature during the experimental period was typical for the autumn season $\left(17-21^{\circ} \mathrm{C}\right)$; the $\mathrm{pH}$ was previously alkali, and as a result of acidification was neutral; TDS decreased during the first two weeks, and afterwards increased as a result of evaporation. The prevailing evaporation influencing the ecosystem parameters at each of the stations confirms that the self-purification process came to an end. Chlorophyll, which was used as a trophic marker, had a low value at pool I, corresponding to an ultra-oligotrophic till oligotrophic level of the ecosystem. However, at pools II and III we revealed oligomesotrophic till eutrophic level of the ecosystem. These results revealed a gradient of organic matter in the experimental pools. This trophic level assessment is relevant to chemical analysis and indices of pollution, which we describe previously (Tavassi et al. 2005).

The algal diversity found on the glass slide accretions in each of the experimental pools was of about 10-15 species each. At the Nofarim station, maximal diversity was reached by the end of experiment, but, at the other stations, was already observed by the $3^{\text {nd }}$ week. Algal cell counts in pools II and III were significantly higher than those in pool I.

During the experiment cells from pool I grew larger (1-2.5 $\left.\mu \mathrm{m}^{3}\right)$; big cell species had some advantage in those systems, in comparison to the two other pools $\left(0.1-1.4 \mu \mathrm{m}^{3}\right)$. This process of cell size decreasing, which appears in all experiment pools, causing an increase in ecosystem entropy indicates that the ecosystems are under environmental stress.

Overall, the experimental study showed that colonization of artificial substrates by algae during the rainy period depends on an initial trophic level and takes about 2-3 weeks. A detailed observation of the self-purification process can be conducted by monitoring diversity dynamics, cell counts, and biomass. Mean specific cell surface or the mean specific biomass in the ecosystem can serve as "system health" criteria for water objects. These criteria may be used for the monitoring of water quality for aquatic ecosystems and in the management of rivers, wastewater reservoirs, etc., in Israel.

Acknowledgements. We thank Yonatan Raz from the Yarqon River Authority, who collaborated on chemical analyses. This work has been partially funded by the Israel Ministry of Absorption. 


\section{REFERENCES}

[1] Ács, É., Reskóné, N.M., Szabó, K., Taba, G.Y., Kiss, K.T. (2005): Application of epiphytic diatoms in water quality monitoring of Lake Velence - recommendations and assignments. - Acta Botanica Hungarica 47(3-4):211-223.

[2] Barinova, S.S., Medvedeva, L.A. (2004): On technique of quantitative account of microphytobenthos in small rivers of Russian Far East. - Algologia 14(1):101-110.

[3] Biggs, B.J.F. (1996): Patterns of benthic algae in streams. - In: Algal Ecology: Freshwater Benthic Ecosystems. R. J. Stevenson, M. Bothwell, and R. L. Lowe. pp. 31-55. Academic Press, San Diego, California, USA.

[4] Biggs, B.J.F. (1988): Algal proliferation in New Zealand's shallow stony foothillisfed rivers: Toward a predictive model. - Verh-Int. Ver Theor Angew Limnol 23:1405-1411.

[5] Biggs, B.J.F. (2000): Eutrophication of streams and rivers: dissolved nutrientchlorophyll relationships for benthic algae. - J.N. Am. Benthol Soc 19:17-31.

[6] Bourassa, N., Cattaneo, A. (1998): Control of periphyton biomass in Laurentian streams (Quebec). - Journal of the North American Benthological Society 17(4):420429.

[7] Cardoso, A.C., Solimini, A.G., Premazzi, G. (2005): Report on Harmonisation of freshwater biological methods. - EUR 21769 EN, European Communities.

[8] Dodds, W.K., Jones, J.R., Welch, E.B. (1998): Suggested classification of stream trophic status: Distribution of temperate stream types by chlorophyll, total nitrogen and phosphorus. - Water Research 32:1455-1462.

[9] European Parliament (2000): Directive 2000/60/EC of the European Parliament and of the Council establishing a framework for Community action in the field of water policy. - Official Journal L327:1-72.

[10] Felfoldy, L. (1987): Biological methods for the classification of water quality. Vizugyl Hidrobiologia 16., VIZDOK Budapest (in Hungarian).

[11] Gafny, S., Goren, M., Gasith, A. (2000): Habitat condition and fish assemblage structure in a coastal Mediterranean stream (Yarqon, Israel) receiving domestic effluent. - Hydrobiologia. 422/423: 319-330.

[12] Gold, C., Feurtet-Mazel, A., Coste, M., Boudou, A. (2002): Field transfer of periphytic diatom communities to assess short-term structural effects of metals $(\mathrm{Cd}$, Zn) in rivers. - Water Research 36: 3654-3664.

[13] Heiskary, S., Markus, H. (2003): Establishing relationships among in-stream nutrient concentrations, phytoplankton abundance and composition, fish IBI and biochemical oxygen demand in Minnesota USA Rivers. - Final report to USEPA Region V. Minnesota pollution control Agency, Environmental Outcomes Division. Minnesota pollution control Agency.

[14] Hillebrand, H., Dürselen, C.D., Kirschtel, D., Pollingher, U., Zohary, T. (1999): Biovolume calculation for pelagic and benthic microalgae. - Journal of Phycology 35(2): 403-424.

[15] King, R.S., Richardson, C.J. (2003): Integrating bioassessment and ecological risk assessment: an approach to developing numerical water-quality criteria. Environmental Management 31(6): 795-809.

[16] Lowe, R.L., Pan, Y. (1996): Benthic algal communities as biological monitors. - In: Stevenson, R.J., Bothwell, M.L., Lowe, R.L. editors. Algal ecology of freshwater benthic ecosystems, aquatic ecology series. Boston: Academic Press: 705-39.

[17] McCormick, P.V., Cairns, Jr.J. ( 1994): Algae as indicators of environmental change. -J Appl Phycol 6: 509-26. 
[18] Padisák, J., Ács, É., Rajczy, M., Kiss, K.T. (1991): Use of algae for monitoring rivers in Hungary. - In: Whitton, B.A., Rott, E. \& Friedrich, G. (eds.) Use of algae for monitoring rivers. Innsbruck: Institut für Botanik Univ Press: 123-128.

[19] PhycoTech - Technical Approach. (2007): http://www.phycotech.com/technical.html

[20] Thompson, R.C., Tobin, M.L., Hawkins, S.J. \& Norton, T.A. (1999): Problems in extraction and spectrophotometric determination of chlorophyll from epilithic microbial biofilms: towards a standard method. - Journal of the Marine Biological Association of the UK 79: 551-558.

[21] Sládečkova, A. (1962): Limnological investigation methods for the periphyton (aufwouch) community. - Bot Rev 28: 286-350.

[22] Stirling, G., Wilsey, B. (2001): Empirical relationships between species richness, evenness, and proportional diversity. - The American Naturalist 158(3): 286-299.

[23] Tavassi, M., Barinova, S.S., Nevo, E., Wasser, S. P. (2007): Water quality assessment along the Yarqon River (central Israel) based on algal indication and bioassay methods. - Hydrobiological Journal (in press).

[24] Tavassi, M., Barinova, S.S., Anissimova, O.V., Nevo, E., Wasser, S.P. (2004): Algal indicators of environment in the Nahal (River) Yarqon basin, central Israel. International Journal on Algae 6(4): 355-382.

[25] Thébault, E., Loreau, M. (2005): Trophic interactions and the ralationship between species diversity and ecosystem stability. - The American Naturalist 166: E95-E114

[26] Tilman, D. (1996): Biodiversity: population versus ecosystem stability. - Ecology 77(2): 350-363.

[27] Wetzel, R.G. Westlake, D.F. (1969): Periphyton. - In: Vollenweider, R.A. (Ed.), A manual on methods for measuring primary production in aquatic environments, Blackwell Scientific Publications, Oxford and Edinburgh: 33-40. 